\title{
Vertical Distribution of Pratylenchus spp. in Silt Loam Soil and Pacific Northwest Dryland Crops
} Richard W. Smiley, Professor, Jason G. Sheedy, Faculty Research Assistant, and Sandra A. Easley, Faculty Research
Assistant, Oregon State University, Columbia Basin Agricultural Research Center, P.O. Box 370, Pendleton, OR 97801

\begin{abstract}
Smiley, R. W., Sheedy, J. G., and Easley, S. A. 2008. Vertical distribution of Pratylenchus spp. in silt loam soil and Pacific Northwest dryland crops. Plant Dis. 92:1662-1668.

Dryland field crops in the Pacific Northwest United States are commonly produced in silt loams infested by the root-lesion nematodes Pratylenchus neglectus and P. thornei. Soils at 30 sites in Oregon were sampled from 0 to $120 \mathrm{~cm}$ depth to examine the vertical distribution of these Pratylenchus spp. Both species were distributed through entire soil profiles of all cropping systems. Populations were generally greatest in the surface $30 \mathrm{~cm}$, but sometimes high populations were detected at depths greater than $45 \mathrm{~cm}$. Sampling to $30 \mathrm{~cm}$ depth allowed detection of more than $50 \%$ of the population in most sites, while sampling to $45 \mathrm{~cm}$ depth yielded more than $75 \%$ of the population in over $75 \%$ of the sites evaluated. Therefore, soil samples should be collected to 30 to $45 \mathrm{~cm}$ depth to accurately estimate populations of Pratylenchus spp. in dryland crops produced on silt loams in the Pacific Northwest. Populations of Pratylenchus spp. were found to be related to the most recently planted crop, with populations after barley, after wheat, and during summer fallow being detected in ascending order.
\end{abstract}

Additional keywords: chemical fallow, cultivated summer fallow, Hordeum vulgare, mustard, Sinapsis alba, Triticum aestivum

The root-lesion nematodes Pratylenchus neglectus (Rensch, 1924) Filipjev \& Schuurmanns Stekhoven, 1941 and $P$. thornei Sher \& Allen, 1953 are migratory root endoparasites that feed and reproduce in the cortex of field crops such as wheat (Triticum aestivum L.), canola (Brassica napus L.), chickpea (Cicer arietinum L.), and barley (Hordeum vulgare L.) $(3,27,28)$. These species penetrate roots and migrate within root tissues by a combination of stylet thrusting and enzymatic softening of the host cell walls (3), causing extensive damage to epidermal and cortical cells. Reduction in crop yield varies greatly in response to climatic and edaphic conditions, and to the level of tolerance or intolerance exhibited by individual cultivars and crops $(3,19,27,28)$. P. neglectus and $P$. thornei have caused as much as $36 \%$ reduction in wheat yields in Oregon $(18,20,21)$. One or both species have been detected in approximately $90 \%$ of fields sampled in the Pacific Northwest (PNW) states of Idaho, Oregon, and Washington $(5,18,22)$. P. neglectus has been detected more frequently than $P$. thornei in these surveys of PNW fields.

Corresponding author: R. W. Smiley

E-mail: richard.smiley@oregonstate.edu

Accepted for publication 28 August 2008.

doi:10.1094/PDIS-92-12-1662

(C) 2008 The American Phytopathological Society
Representative sampling of plantparasitic nematodes is essential to correlate yield loss with nematode density and to assess management strategies. Sampling to a depth of $20 \mathrm{~cm}$ is commonly recommended $(11,17)$ but sampling to 10 to 20 $\mathrm{cm}$ depth in Oregon resulted in negative correlation of grain yield with population of Pratylenchus spp. $(18,20,21)$ in only half the experiments performed. In the other experiments (unpublished data), yield improvements from application of the nematicide aldicarb could not be correlated with Pratylenchus spp. or any other organism likely to affect wheat yield and also be sensitive to aldicarb. Furthermore, application of aldicarb to a field with a very low population of Pratylenchus spp. did not alter grain yield (20).

Vertical distribution of plant-parasitic nematodes is affected by factors such as distribution of host root system, soil temperature and $\mathrm{pH}$, soil type and moisture content, vertical migration, and mortality rates that vary with soil depth $(3,12,14)$. $P$. neglectus and $P$. thornei have been detected as deep as $120 \mathrm{~cm}$ in Australia (4,23,25). Taylor and Evans (23) reported that sampling to $20 \mathrm{~cm}$ depth detected more than $60 \%$ of the total population of these species. Doyle et al. (4) detected a greater population in the surface $15 \mathrm{~cm}$ during a moist year and at 30 to $60 \mathrm{~cm}$ depth during a dry year. Thompson et al. (25) detected less than $20 \%$ of the total population in the top $15 \mathrm{~cm}$ and a maximum population density at 20 to $30 \mathrm{~cm}$ depth. Vertical distributions of Pratylenchus spp. have not been reported for the silt loams used to produce most dryland field crops in the PNW.

The objectives of this study were to: (i) examine the vertical distribution of Pratylenchus spp. in nonirrigated silt loams in eastern Oregon; (ii) determine whether representative cropping systems affect the vertical distribution of Pratylenchus spp.; and (iii) identify an optimum soil sampling depth to detect populations of Pratylenchus spp. in the most common cropping systems. Field-specific profile distributions for Pratylenchus spp. are reported.

\section{MATERIALS AND METHODS}

Sampling procedures. Soil cores were collected using a tractor-mounted Giddings GSTRS Hydraulic Soil Sampler with a 5cm-diameter, 150-cm-long slotted soil tube and heavy-duty bit (Giddings Machine Company, Windsor, CO). A pair of soil cores were collected $1 \mathrm{~m}$ apart at each sampling location to ensure sufficient soil was collected for each depth interval and to minimize the effect of the inherent spatial variability of Pratylenchus spp. Within each field or experimental plot, sampling intensity varied from one location per 160 to $360 \mathrm{~m}^{2}$ in experimental plots to one location per 263 to $638 \mathrm{~m}^{2}$ in areas of interest in commercial fields. These sampling intensities exceeded the density of one location per $1,575 \mathrm{~m}^{2}$ considered necessary for effectively characterizing $P$. thornei populations (25). Sampling depths ranged from 45 to $120 \mathrm{~cm}$, depending upon the depth to bedrock or other restrictive layer. Soil cores were separated into $15-\mathrm{cm}$ intervals from 0 to $60 \mathrm{~cm}$ depth and into $30-\mathrm{cm}$ intervals from 60 to $120 \mathrm{~cm}$ depth. Corresponding intervals from the pair of cores taken from a sampling location were composited into samples and stored at $4{ }^{\circ} \mathrm{C}$ until processed.

The Whitehead tray method (29) was used to extract nematodes. Plastic mesh was cut to size and fitted inside a plasticcoated wire tray that was then placed into a $32 \times 40 \mathrm{~cm}$ flat-bottomed plastic tub. Two 2-ply facial tissues, slightly overlapping, were laid over the plastic mesh. A 200-g subsample from a thoroughly mixed soil sample was spread in a 1-cm layer over the tissues. One liter of tap water was added to the plastic tub so that the water level in the tray was enough to moisten the soil but not to cause water logging. Nematodes from 
soil and root segments were collected in the reservoir of water. Samples were extracted for $48 \mathrm{~h}$ in a constant-temperature room $\left(22^{\circ} \mathrm{C}\right)$, which would provide an extraction efficiency of approximately $77 \%$ (1). The basket was then lifted out of the water and allowed to drain before the tissue and soil were discarded. Water in the tub was agitated and poured through a 20 $\mu \mathrm{m}$ sieve. The tub was rinsed once and the water was passed through the sieve. The sieve was then rinsed twice with minimal water volume and the suspension containing nematodes was collected in a 30-ml vial. The volume of extract was determined and samples were stored at $4{ }^{\circ} \mathrm{C}$.

Assessments of nematode populations extracted from soil and roots were made using a Chalex Corporation (Issaquah, WA) grid-style nematode-counting slide, based on the Hawksley slide design. The aqueous suspension was mixed, and a 1-ml subsample was placed on the counting slide for examination at $\times 100$ magnification. Numbers of Pratylenchus spp. were recorded and the species present were determined by morphometric assessment (6). Gravimetric soil moisture content of each sample was determined by drying a 100-g subsample from each soil sample for $48 \mathrm{~h}$ at $105^{\circ} \mathrm{C}$. Populations were expressed as nematodes per $\mathrm{kg}$ of oven-dry soil.

Sampling locations and sites. An earlier soil survey (18) identified locations near Heppner, Moro, and Pendleton, OR suitable for detailed studies of Pratylenchus spp. distributions in soil profiles. Sampling sites included long-term research plots (0.05 to $0.2 \mathrm{ha}$ ) and 0.3 - to 1.0 -ha portions of commercial fields with differing crop histories and tillage management. The sites, along with the area sampled and numbers of samples collected, are listed in Table 1 .

$P$. neglectus was sampled in six plots of a long-term experiment (10) at the Center of Sustainability (COS) and in nearby commercial fields near Heppner, Morrow County, OR. Precipitation averages 312 $\mathrm{mm}$ annually, nearly all of which occurs from late autumn (October) through spring (May). Soil is a shallow (45 to $120 \mathrm{~cm}$ ) Valby silt loam; fine-silty, mixed, superactive, mesic Calcic Haploxeroll. Samples were collected from $24 \times 91 \mathrm{~m}$ experimental plots (COS nos. 111-116) on 10 June 2005 and 24 May 2006. Treatments in the plots included 'Stephens' soft-white winter wheat rotated with chemical fallow (COS111; since 2000), annual no-till 'Jefferson' hard-red spring wheat (COS112; since 1996), annual no-till 'Alpowa' softwhite spring wheat (COS113; since 1996), annual no-till 'Baronesse' spring barley (COS114; since 1996), and both phases of 'Stephens' winter wheat rotated with conventionally cultivated fallow (COS115, COS116; continuation of the historical practice for the region).

Eleven commercial fields near Heppner were sampled from 2005 to 2007 to complement comparisons of cropping history and frequency with COS experimental fields. Samples were collected on 10 June 2005 from Field 4 (F4), which was planted to winter wheat in October 2004 following a 14-month chemical fallow, and planted to wheat annually from 1999 to 2003. On 26 September 2005, samples were collected from each of three no-till fields: (i) the Dale Brown Road Field 1 (DBRF1), which had been without tillage since 1996 and was planted to 'Tilney' yellow mustard (Sinapsis alba L.) in 2005, soft-white spring wheat in 2004, winter wheat harvested in 2003, spring barley from 1999 to 2002, spring mustard in 1998, spring barley in 1997, and spring wheat in 1996; (ii) O'Neill Field 1 (ONF1), which had been maintained without tillage since 1997 and was planted to 'Baronesse' spring barley in 2004 and 2005, to winter wheat harvested in 2003, and mostly to spring barley between 1997 and 2003; and (iii) Field 7 (F7), which was chemically fallowed during 2005, and planted to 'Dirkwin' softwhite spring wheat during 2004 and to 'Stephens' winter wheat in 2002 and 2003. Two commercial fields (ONF1 and DBRF1) that were sampled in 2005 were sampled again on 11 May 2006, at different locations than in 2005. In 2006, fields ONF1 and DBRF1 contained stands of 'Alpowa' spring wheat and 'Baronesse' spring barley, respectively. Also in 2006, samples were collected on 13 July from two locations in a field that had been maintained as a mixed planting of intermediate wheat grass (Thinopyrum intermedium (Host) Barkworth \& D.R. Dewey), sheep fescue (Festuca ovina L.), and Siberian wheat grass (Agropyron fragile (Roth) $\mathrm{P}$. Candargy) from about 1988 to 2006. In 2006, the soil was cultivated and the northern half (Liberty School Road FieldNorth; LSRFN) was planted to 'Dirkwin' spring wheat and the southern half (LSRFS) to 'Twin' spring wheat. On 11 May 2007, samples were collected from Logan Lane Fields 1 and 2 (LLF1, LLF2), both of which were planted to 'ORCF-101' winter wheat in 2006 and annual winter wheat since 2002. Samples were also collected from DBRF1 containing 'Belford' spring barley, at a different location than sampled in 2005 and 2006, and from Dale

Table 1. Summary of sampling locations, years, and sites for assessing distributions of Pratylenchus spp. in 30 soil profiles in Oregon

\begin{tabular}{|c|c|c|c|c|c|c|c|}
\hline \multirow[b]{2}{*}{ Location } & \multirow[b]{2}{*}{ Year } & \multirow[b]{2}{*}{ Sampling site type (field or experiment) and name } & \multirow[b]{2}{*}{ Designation } & \multirow[b]{2}{*}{ Area (m) } & \multirow[b]{2}{*}{ Crop $^{b}$} & \multicolumn{2}{|c|}{ Samples collected $^{\mathrm{a}}$} \\
\hline & & & & & & No./site & Total \\
\hline \multirow{13}{*}{ Heppner } & \multirow[t]{4}{*}{2005} & Experiment: "Center of Sustainability", 6 treatments & $\operatorname{COS} 111-116$ & $20 \times 90$ & SW, WW, SB, SF & 5 & 30 \\
\hline & & Field 4 & $\mathrm{~F} 4$ & $30 \times 340$ & WW & 16 & 16 \\
\hline & & Dale Brown Road Field 1 & DBRF1 & $30 \times 90$ & SM & 6 & 6 \\
\hline & & O’Neill Field 1 & ONF1 & $45 \times 60$ & SB & 6 & 6 \\
\hline & \multirow[t]{5}{*}{2006} & Experiment: "Center of Sustainability", 6 treatments & $\operatorname{COS} 111-116$ & $20 \times 90$ & SW, WW, SB, SF & 5 & 30 \\
\hline & & Dale Brown Road Field 1 & DBRF1 & $45 \times 60$ & SB & 6 & 6 \\
\hline & & O’Neill Field 1 & ONF1 & $80 \times 100$ & SW & 27 & 27 \\
\hline & & Liberty School Road Field-North & LSRFN & $60 \times 90$ & MG & 9 & 9 \\
\hline & & Liberty School Road Field-South & LSRFS & $60 \times 90$ & MG & 9 & 9 \\
\hline & \multirow{4}{*}{2007} & Dale Brown Road Field 1 & DBRF1 & $45 \times 60$ & SW & 6 & 6 \\
\hline & & Dale Brown Road Field 2 & DBRF2 & $45 \times 60$ & SM & 6 & 6 \\
\hline & & Logan Lane Field 1 & LLF1 & $45 \times 60$ & WW & 6 & 6 \\
\hline & & Logan Lane Field 2 & LLF2 & $45 \times 60$ & WW & 6 & 6 \\
\hline Moro & 2006 & Four-corners Field & MSW & $20 \times 30$ & SW & 6 & 6 \\
\hline \multirow[t]{6}{*}{ Pendleton } & \multirow[t]{2}{*}{2005} & Field B1 & B1 & $60 \times 90$ & SW & 12 & 12 \\
\hline & & Adams Field 1 & $\mathrm{AF} 1$ & $35 \times 135$ & WW & 18 & 18 \\
\hline & \multirow[t]{2}{*}{2006} & Adams Field 3 & AF3 & $35 \times 135$ & WW & 9 & 9 \\
\hline & & Adams Field 5 & AF5 & $35 \times 135$ & WW & 12 & 12 \\
\hline & \multirow[t]{2}{*}{2007} & Adams Field 2 & AF2 & $35 \times 135$ & SW & 9 & 9 \\
\hline & & Adams Field 6 & AF6 & $35 \times 135$ & WW & 12 & 12 \\
\hline
\end{tabular}

\footnotetext{
${ }^{\text {a }}$ Each sample consisted of a composite of two soil cores collected $1 \mathrm{~m}$ apart, each of which was divided into 15 to $30 \mathrm{~cm}$ depth intervals to a depth of 120 $\mathrm{cm}$. A restrictive layer (basalt or caliche) at some locations and for individual samples prevented the collection of soil cores to the full $120 \mathrm{~cm}$ depth.

${ }^{\mathrm{b}}$ Current or most recent crop or treatment on the sampling site (see text for details): $\mathrm{SW}=$ spring wheat, $\mathrm{WW}=$ winter wheat, $\mathrm{SB}=$ spring barley, $\mathrm{SM}=$ spring mustard, $\mathrm{MG}=$ mixed perennial grasses, $\mathrm{SF}=$ summer fallow.
} 
Brown Road Field 2 (DBRF2), which had been without tillage since 1996 and was planted to three spring wheat and two winter wheat crops from 2003 to 2007, spring barley from 1997 to 2002, and winter wheat in 1996.

A field at the Columbia Basin Agricultural Research Center near Moro, Sherman County, OR was sampled for P. neglectus. Annual precipitation averages $280 \mathrm{~mm}$, and soil is a moderately deep $(>120 \mathrm{~cm})$ Walla Walla silt loam; coarse-silty, mixed, superactive, mesic Typic Haploxeroll. Spring wheat had been planted annually without tillage since 1999. Samples were collected on 1 June 2005.

$P$. thornei populations were determined from samples collected from six no-till fields at the Columbia Basin Agricultural Research Center near Pendleton, Umatilla County, OR. Annual precipitation averages $400 \mathrm{~mm}$, and soil is a variable depth (60 to $150 \mathrm{~cm}$ ) Walla Walla silt loam. Field B1 had continuous no-till spring wheat cultivars since 2002: 'Alpowa' from 2002 to 2003 and 'Zak' from 2004 to 2006. Adams Field 1 (AF1) was in spring wheat in 2002, winter wheat during 2003, chemical fallow in 2004, and 'Tubbs' soft white winter wheat in 2005. Adams Field 2 (AF2) was winter wheat during 2003, chemical fallow in 2004, 'Stephens' winter wheat in 2005, 'Zak' spring wheat in 2006, and chemical fallow in 2007. Adams Field 3 (AF3) was in winter wheat during 2003, 'Alpowa' spring wheat in 2004, chemical fallow in 2005, and 'Tubbs' winter wheat in 2006. Adams Field 5 (AF5) was 'Stephens' winter wheat during 2003, 'Zak' spring wheat in 2004 and 2005, chemical fallow in 2006, and a winter wheat variety trial during the 2006-2007 crop year. Adams Field 6 (AF6) was winter wheat during 2003, 'Stephens' winter wheat in 2004, 'Zak' spring wheat in 2005, chemical fallow during 2006, and 'Stephens' winter wheat in 2007. Samples were collected from B1 and AF1 on 27 May 2005, from AF3 and AF5 on 30 May
2006, and from AF2 and AF6 on 10 May 2007.

Statistical analysis. Data were transformed using $\ln (x+1)$ to normalize nematode counts (13) prior to statistical analysis. Back-transformed means are reported. Fields sampled once or at different sites over 2 or 3 years were analyzed individually using one-way ANOVA with depth as treatment and samples for blocks. Data were combined prior to analysis for COS fields sampled in both 2005 and 2006. Cumulative nematode population percentage through the soil profile across all sites and years was analyzed with depth as treatment and sites as blocks, and with crops as treatment and depths as blocks. ANOVA was performed using CoStat Statistical Software version 6.311 (CoHort Software, Monterey, CA). When treatment means were significant at $P<0.05$, means were separated using the least significant difference (LSD) test.

\section{RESULTS}

$P$. neglectus and $P$. thornei were the only species of Pratylenchus detected in the 30 nonirrigated silt loam sites sampled over the 3 years of this study. $P$. neglectus was the dominant or only species detected in fields near Heppner and Moro, while $P$. thorne $i$ was the dominant or only species detected in fields near Pendleton. These species were distributed throughout the profiles at each site examined, and they were detected to $120 \mathrm{~cm}$ depth in deep soils.

When examined across sites and years, sampling the upper $15 \mathrm{~cm}$ of the soil profile in 30 fields and experiments led to the detection of only $32 \%$ of the Pratylenchus population (Table 2). Sampling to 30 and $45 \mathrm{~cm}$ depths yielded 60 and $81 \%$ of the populations, respectively. Similar percentages of detection at the various depths occurred when the results were partitioned among sites currently in summer fallow or most recently planted to spring barley, spring wheat, or winter wheat. Sampling to
$60 \mathrm{~cm}$ depth was required to detect $90 \%$ of the Pratylenchus spp. populations in each of the site categories.

We also evaluated the frequency at which various proportions of the total Pratylenchus spp. population were detected when all intervals to 15,30 , or $45 \mathrm{~cm}$ depth were considered. When only the top 0 to $15 \mathrm{~cm}$ interval of each site was considered, very few $(10 \%)$ of the sites had population levels that represented at least $50 \%$ of the total detectable population (data not presented). In contrast, at least $50 \%$ of the total detectable population was found by sampling to 30 and $45 \mathrm{~cm}$ depth in 63 and $100 \%$ of the sites, respectively. Likewise, more than $70 \%$ of the total detectable population was found at 30 and 45 $\mathrm{cm}$ depth in 30 and $70 \%$ of the sites, respectively.

Although it was not possible to evaluate differences among cropping systems statistically, differences in Pratylenchus spp. population and profile distribution were detected among the sampled sites that appeared to be related to cropping systems. In experimental plots near Heppner with 2year rotations of winter wheat and summer fallow, populations of $P$. neglectus within the 15,30 , and $45 \mathrm{~cm}$ depth intervals were higher during the fallow phase than during the in-crop phase of these rotations (Table 3 ), indicating an overall decline of populations during the 14 months of fallow. More than $40 \%$ of the total P. neglectus population was detected by sampling to $30 \mathrm{~cm}$ depth in these plots, whereas sampling to only $15 \mathrm{~cm}$ depth allowed detection of only 10 to $31 \%$ of the population.

A similar pattern was found in fields near Pendleton with chemical fallowwinter wheat rotations (Table 4). Populations of $P$. thornei in fields in summer fallow following winter wheat tended to exceed those in the winter wheat cropping phase. In all of the fields, $50 \%$ or more of the total $P$. thornei population was detected within the top $30 \mathrm{~cm}$ of the soil profile, and 66 to $82 \%$ of the population was de-

Table 2. Pratylenchus spp. population with increasing soil depth determined from all 30 sites at three locations in Oregon sampled from 2005 to 2007 and from subsets of the sites planted to a crop or managed as summer fallow

\begin{tabular}{|c|c|c|c|c|c|c|c|c|c|c|c|c|c|c|c|}
\hline \multirow{2}{*}{$\begin{array}{l}\text { Soil } \\
\text { depth } \\
(\mathrm{cm})\end{array}$} & \multicolumn{3}{|c|}{ All fields } & \multicolumn{3}{|c|}{ Spring barley } & \multicolumn{3}{|c|}{ Spring wheat } & \multicolumn{3}{|c|}{ Winter wheat } & \multicolumn{3}{|c|}{ Summer fallow } \\
\hline & Mean $^{a}$ & $\begin{array}{c}\text { Incr. } \\
\%^{b}\end{array}$ & $\underset{\% c}{\text { Cum. }}$ & Mean & $\begin{array}{c}\text { Incr. } \\
\%\end{array}$ & $\underset{\%}{\operatorname{Cum}}$ & Mean & $\begin{array}{c}\text { Incr. } \\
\%\end{array}$ & Cum. & Mean & $\begin{array}{c}\text { Incr. } \\
\%\end{array}$ & $\underset{\%}{\text { Cum. }}$ & Mean & $\underset{\%}{\text { Incr. }}$ & $\underset{\%}{\text { Cum. }}$ \\
\hline $0-15$ & 3,403 & 32 & 32 & 714 & 18 & 18 & 3,227 & 32 & 32 & 2,673 & 24 & 24 & 6,154 & 32 & 32 \\
\hline $15-30$ & 3,067 & 28 & 60 & 843 & 25 & 43 & 2,510 & 35 & 67 & 3,760 & 36 & 60 & 4,320 & 24 & 56 \\
\hline $30-45$ & 2,177 & 21 & 81 & 1,050 & 29 & 72 & 1,850 & 20 & 87 & 1,600 & 19 & 79 & 4,079 & 23 & 79 \\
\hline $45-60$ & 1,211 & 12 & 93 & 843 & 20 & 92 & 952 & 9 & 96 & 963 & 15 & 94 & 2,247 & 10 & 89 \\
\hline $60-90$ & 767 & 6 & 99 & 465 & 8 & 100 & 376 & 4 & 100 & 364 & 6 & 100 & 2,036 & 9 & 98 \\
\hline $90-120$ & 105 & 1 & 100 & 7 & 0 & 100 & 99 & 0 & 100 & 62 & 0 & 100 & 201 & 2 & 100 \\
\hline$P>F$ & $<0.001$ & & & 0.079 & & & 0.008 & & & 0.002 & & & $<0.001$ & & \\
\hline $\mathrm{LSD}_{0.05}$ & 1,213 & & & $\mathrm{~ns}$ & & & 2,435 & & & 2,110 & & & 2,610 & & \\
\hline $\mathrm{CV}(\%)$ & 99 & & & 54 & & & 129 & & & 108 & & & 61 & & \\
\hline $\mathrm{n}^{\mathrm{d}}$ & 174 & & & 22 & & & 61 & & & 51 & & & 40 & & \\
\hline
\end{tabular}

a Number of nematodes per kg of soil; values presented are back-transformed means.

b Percentage of the total population found in the indicated soil depth interval.

c Cumulative percentage of the total population from soil surface to the indicated soil depth interval.

${ }^{\mathrm{d}}$ Data points used in the analysis; e.g., (samples/field $\times$ depth intervals) - (missing samples due to a restrictive layer). 
tected in samples collected to $45 \mathrm{~cm}$ depth. In contrast, shallow $(15 \mathrm{~cm})$ samplings yielded only 12 to $41 \%$ of the population. Populations of $P$. thornei exceeding 10,000 per $\mathrm{kg}$ were detected in the 0 to 15 $\mathrm{cm}$ intervals from some of the individual samples collected in fields AF1 and AF5, both of which contained winter wheat (data not shown).

In 2 years sampling of experimental plots near Heppner with different continuous cropping systems, plots cropped with wheat had much higher populations of $P$. neglectus compared to the plot containing barley (Table 5). Sampling to only $15 \mathrm{~cm}$ depth yielded highly variable (14 to $48 \%$ ) proportions of the total population. More than $50 \%$ of the population in each plot was found by sampling to $45 \mathrm{~cm}$ depth. Populations of $P$. neglectus tended to be higher in plots with winter wheat than with spring wheat.
These patterns also were observed in nearby commercial fields. In fields sampled in 2007, higher populations of $P$. neglectus were detected in fields with winter wheat than in a field with spring wheat (Table 6). The potential for barley to reduce $P$. neglectus populations was particularly apparent from sampling the DBRF1 field near Heppner over 3 years (Fig. 1). A very high population of $P$. neglectus (up to 10,934 per $\mathrm{kg}$ ) was detected throughout the $90-\mathrm{cm}$ soil profile following a spring mustard crop in 2005. When the field was resampled in 2006, following a crop of barley, $P$. neglectus populations at all depths had decreased to very low levels. The $P$. neglectus populations then increased when sampled again during the spring wheat crop in 2007. Likewise, the O'Neil Road Field 1 in 2005, following two successive barley crops, had a $P$. neglectus population of 700 per $\mathrm{kg}$ of soil at
0 to $30 \mathrm{~cm}$ depth and 1,426 per $\mathrm{kg}$ in the 45 to $60 \mathrm{~cm}$ depth interval. The populations increased to 972 and 1,444 per $\mathrm{kg}$, respectively, 1 year later following the planting of spring wheat (data not shown).

Populations of Pratylenchus spp. were less than 1,000 per $\mathrm{kg}$ of soil in two portions of a field previously in mixed perennial grasses (LSRFN and LSRFS) and planted to spring wheat (data not shown). Samples collected to $15 \mathrm{~cm}$ depth yielded 43 and $72 \%$ of the populations in the two portions of the field, while sampling to 30 $\mathrm{cm}$ depth resulted in detection of over $96 \%$ of the population.

\section{DISCUSSION}

P. neglectus, $P$. thornei, or mixtures of these species were detected throughout the silt loam profiles at 30 nonirrigated sites in Oregon. In deep soils, these Pratylenchus spp. were detected even at the greatest

Table 3. Vertical distribution of Pratylenchus neglectus populations in six soil depth increments collected during 2005 and 2006 from 2 -year rotations of soft white winter wheat (SWWW) with either no-till chemical summer fallow (ChemF) or conventionally cultivated fallow (ConvF) in a long-term experiment near Heppner, OR

\begin{tabular}{|c|c|c|c|c|c|c|c|c|c|c|c|c|}
\hline \multirow{2}{*}{$\begin{array}{l}\text { Soil } \\
\text { depth } \\
(\mathbf{c m})\end{array}$} & \multicolumn{3}{|c|}{$\begin{array}{l}\text { SWWW-ChemFa } \\
\text { (COS111: 2005) }\end{array}$} & \multicolumn{3}{|c|}{$\begin{array}{l}\text { ChemF-SWWW } \\
\text { (COS111: 2006) }\end{array}$} & \multicolumn{3}{|c|}{$\begin{array}{c}\text { SWWW-ConvF } \\
\text { (COS115: 2005; COS116: 2006) }\end{array}$} & \multicolumn{3}{|c|}{$\begin{array}{c}\text { ConvF-SWWW } \\
\text { (COS116: 2005; COS115: 2006) }\end{array}$} \\
\hline & Mean $^{b}$ & Incr. $\%$ c & Cum. \%d & Mean & Incr. \% & Cum. \% & Mean & Incr. \% & Cum. \% & Mean & Incr. \% & Cum. \% \\
\hline $0-15$ & 727 & 13 & 13 & 6,007 & 23 & 23 & 791 & 10 & 10 & 4,338 & 31 & 31 \\
\hline $15-30$ & 1,501 & 27 & 41 & 7,198 & 28 & 51 & 3,286 & 42 & 51 & 3,722 & 27 & 58 \\
\hline $30-45$ & 987 & 18 & 59 & 7,905 & 31 & 82 & 2,425 & 31 & 82 & 4,525 & 32 & 90 \\
\hline $45-60$ & 1,971 & 36 & 94 & 3,207 & 12 & 94 & 1,405 & 18 & 100 & 1,080 & 8 & 98 \\
\hline $60-90$ & 306 & 6 & 100 & 1,537 & 6 & 100 & 9 & 0 & 100 & 262 & 2 & 100 \\
\hline $90-120$ & 0 & 0 & 100 & 38 & 0 & 100 & - & 0 & 100 & 25 & 0 & 100 \\
\hline$P>F$ & 0.006 & & & $<0.001$ & & & $<0.001$ & & & $<0.001$ & & \\
\hline $\mathrm{LSD}_{0.05}$ & 40 & & & 5 & & & 10 & & & 29 & & \\
\hline $\mathrm{CV}(\%)$ & 28 & & & 15 & & & 27 & & & 23 & & \\
\hline $\mathrm{n}^{\mathrm{e}}$ & 25 & & & 28 & & & 43 & & & 49 & & \\
\hline
\end{tabular}

a First-listed treatment in each rotation indicates the phase of the rotation sampled. Plot designation and year of sampling are in parentheses. COS111 consisted of two plots with alternating treatments of winter wheat and chemical fallow. COS115 and COS116 were offset duplicates of a rotation of winter wheat and conventionally cultivated summer fallow, allowing annual sampling of both phases.

b Means (number of nematodes per kg of soil) and LSD values are back-transformed; means are based on five replicate samples at each depth increment collected at each site during each of the 2 years.

c Percentage of the total population found in the indicated soil depth interval.

${ }^{\mathrm{d}}$ Cumulative percentage of the total population from soil surface to the indicated soil depth interval.

e Data points used in the analysis.

Table 4. Vertical distribution of Pratylenchus thornei populations in soft white winter wheat (SWWW) and chemically fallowed phases of 3-year no-till rotations at the Columbia Basin Agricultural Research Center near Pendleton, OR

\begin{tabular}{|c|c|c|c|c|c|c|c|c|c|c|c|c|c|c|c|}
\hline \multirow{2}{*}{$\begin{array}{l}\text { Soil } \\
\text { depth } \\
(\mathrm{cm})\end{array}$} & \multicolumn{3}{|c|}{$\begin{array}{c}\text { Field AF1 (2005) } \\
\quad(\text { SWWW) }\end{array}$} & \multicolumn{3}{|c|}{$\begin{array}{c}\text { Field AF3 (2006) } \\
\quad(\text { SWWW) }\end{array}$} & \multicolumn{3}{|c|}{$\begin{array}{l}\text { Field AF5 (2006) } \\
\text { (chemical fallow) }\end{array}$} & \multicolumn{3}{|c|}{$\begin{array}{c}\text { Field AF6 (2007) } \\
\quad \text { (SWWW) }\end{array}$} & \multicolumn{3}{|c|}{$\begin{array}{l}\text { Field AF2 (2007) } \\
\text { (chemical fallow) }\end{array}$} \\
\hline & Mean $^{a}$ & $\begin{array}{l}\text { Incr. } \\
\% \text { b }\end{array}$ & $\underset{\% c}{\text { Cum. }}$ & Mean & $\begin{array}{c}\text { Incr. } \\
\%\end{array}$ & $\underset{\%}{\text { Cum. }}$ & Mean & $\begin{array}{c}\text { Incr. } \\
\%\end{array}$ & $\underset{\%}{\text { Cum. }}$ & Mean & $\begin{array}{c}\text { Incr. } \\
\%\end{array}$ & $\underset{\%}{\text { Cum. }}$ & Mean & $\begin{array}{c}\text { Incr. } \\
\%\end{array}$ & $\underset{\%}{\text { Cum. }}$ \\
\hline $0-15$ & 507 & 12 & 12 & 3,644 & 41 & 41 & 12,092 & 35 & 35 & 3,587 & 28 & 28 & 4,406 & 37 & 27 \\
\hline $15-30$ & 1,598 & 38 & 50 & 2,954 & 33 & 74 & 6,627 & 19 & 54 & 3,652 & 29 & 57 & 3,523 & 22 & 49 \\
\hline $30-45$ & 759 & 18 & 68 & 666 & 8 & 82 & 3,870 & 11 & 66 & 1,789 & 14 & 71 & 3,600 & 22 & 72 \\
\hline $45-60$ & 758 & 18 & 86 & 794 & 9 & 91 & 5,999 & 17 & 83 & 2,783 & 22 & 93 & 2,290 & 14 & 86 \\
\hline $60-90$ & 540 & 13 & 99 & 664 & 7 & 98 & 5,650 & 16 & 100 & 844 & 7 & 100 & 2,176 & 14 & 100 \\
\hline $90-120$ & 33 & 1 & 100 & 139 & 2 & 100 & 168 & 0 & 100 & 10 & 0 & 100 & 53 & 0 & 100 \\
\hline$P>F$ & $<0.001$ & & & $<0.001$ & & & $<0.001$ & & & $<0.001$ & & & $<0.001$ & & \\
\hline $\mathrm{LSD}_{0.05}$ & 2 & & & 4 & & & 4 & & & 5 & & & 3 & & \\
\hline $\mathrm{CV}(\%)$ & 36 & & & 20 & & & 18 & & & 22 & & & 18 & & \\
\hline$n^{d}$ & 110 & & & 54 & & & 72 & & & 72 & & & 54 & & \\
\hline
\end{tabular}

a Means (number of nematodes per kg of soil) and LSD values are back-transformed; means for fields AF1, AF3, AF5, AF6, and AF2 are based on 18, 9, 12, 12 , and 18 replicates per depth increment, respectively.

b Percentage of the total population found in the indicated soil depth interval.

${ }^{c}$ Cumulative percentage of the total population from soil surface to the indicated soil depth interval.

${ }^{\mathrm{d}}$ Data points used in the analysis. 
depth sampled $(120 \mathrm{~cm})$, as previously reported in Australia $(4,25)$. Sampling to a depth of $15 \mathrm{~cm}$, as used in earlier surveys of these species in the PNW $(5,18,22)$ and in assessments of their impact on wheat yield (20,21), appears to reveal less than $30 \%$ of the total populations present in the soil profiles. More than $50 \%$ of the populations were detected at all sites by sampling to $30 \mathrm{~cm}$ depth, and more than $75 \%$ were detected in three-quarters of all sites sampled to $45 \mathrm{~cm}$ depth. These results indicated that sampling to $15 \mathrm{~cm}$ depth was useful for indicating presence or absence of these species, but not always as a reliable indicator of populations throughout the soil profile. We conclude that soil samples must be collected to a depth of 30 to $45 \mathrm{~cm}$ to provide reliable estimates of Pratylenchus spp. populations in PNW silt loams.

Crop history had an important influence on total Pratylenchus spp. populations as well as soil profile distributions. Populations were lower in crop sequences that included barley than in crop sequences with wheat grown annually or in wheatfallow rotation. Barley is an effective rotation crop in Pratylenchus-infested soil due to its greater tolerance and resistance to $P$. thornei and P. neglectus $(4,7,16,18,24,26)$.

Smiley et al. (18) reported that populations of Pratylenchus spp. were higher in annually cropped fields than in wheatfallow rotations, based on samples collected at 10 to $20 \mathrm{~cm}$ depth. This study demonstrated that shallow sampling was responsible for our earlier conclusion that crop loss assessment experiments should be focused on fields cropped annually (10\% of the production area) rather than on fields managed as wheat-fallow rotations (90\% of production). We determined that proportions of the Pratylenchus spp. population recovered in the surface $15 \mathrm{~cm}$ at low rainfall sites such as Heppner and Moro were generally higher (20 to $48 \%$ ) for annual field crops than for winter wheat-summer fallow rotations (13 to
Table 6. Vertical distribution of Pratylenchus neglectus populations in three commercial wheat fields sampled during 2007 near Heppner, OR

\begin{tabular}{|c|c|c|c|c|c|c|}
\hline \multirow{2}{*}{$\begin{array}{l}\text { Soil depth } \\
\text { (cm) }\end{array}$} & \multicolumn{3}{|c|}{$\begin{array}{l}\text { Field DBRF2 } \\
\text { (spring wheat) }\end{array}$} & \multicolumn{3}{|c|}{$\begin{array}{l}\text { Fields LLF1 and LLF2 } \\
\text { (winter wheat) }\end{array}$} \\
\hline & Mean $^{\mathbf{b}}$ & Incr. $\%$ c & Cum. \% & Mean & Incr. \% & Cum. \% \\
\hline $0-15$ & 4,425 & 38 & 38 & 6,542 & 41 & 41 \\
\hline $15-30$ & 1,155 & 10 & 48 & 5,340 & 34 & 75 \\
\hline $30-45$ & 4,285 & 37 & 85 & 2,367 & 14 & 89 \\
\hline $45-60$ & 338 & 3 & 88 & 1,428 & 8 & 97 \\
\hline $60-90$ & 1,417 & 12 & 100 & 441 & 2 & 99 \\
\hline $90-120$ & - & & & 188 & 1 & 100 \\
\hline$P>F$ & 0.002 & & & $<0.001$ & & \\
\hline $\mathrm{LSD}_{0.05}$ & 1 & & & 3 & & \\
\hline $\mathrm{CV}(\%)$ & 7 & & & 21 & & \\
\hline$n^{e}$ & 22 & & & 61 & & \\
\hline
\end{tabular}

${ }^{a}$ Data for Fields LLF1 and LLF2 did not differ significantly and were pooled.

${ }^{\mathrm{b}}$ Means and LSD are back-transformed; means were based on six replicates per depth increment.

${ }^{c}$ Percentage of the total population found in the indicated soil depth interval.

${ }^{\mathrm{d}}$ Cumulative (from soil surface to that soil depth interval) percentage of the total population.

${ }^{\mathrm{e}}$ Data points used in the analysis.

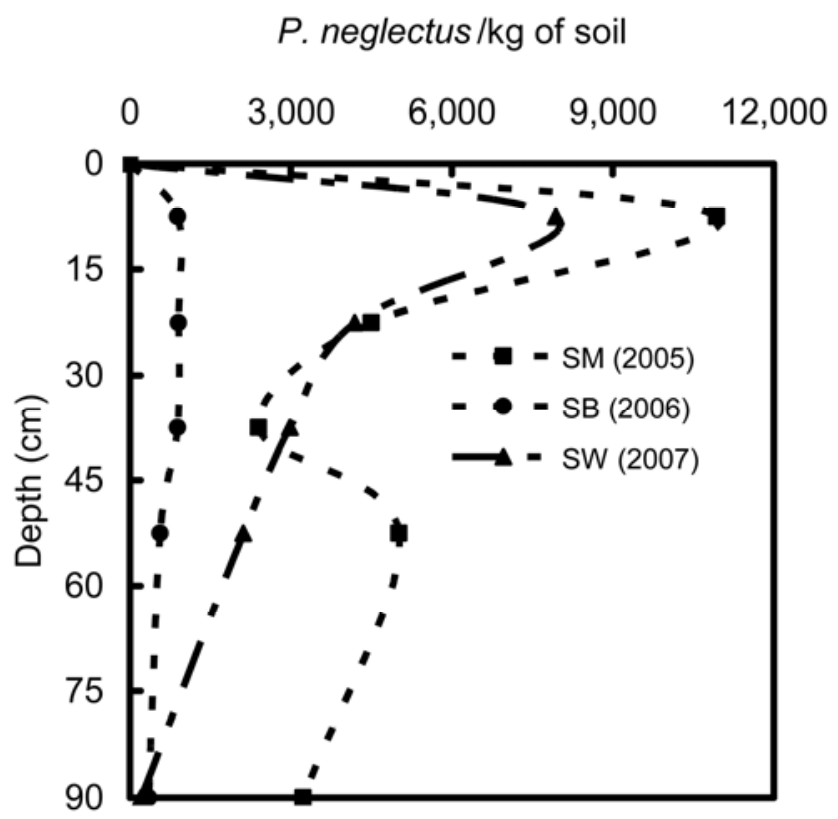

Fig. 1. Population levels of Pratylenchus neglectus at different soil depths following spring mustard (SM; sampled in 2005), spring barley (SB; sampled in 2006), and spring wheat (SW; sampled in 2007) in annually cropped, no-till Dale Brown Road Field 1 (DBRF1) near Heppner, OR.

Table 5. Vertical distribution of Pratylenchus neglectus populations in six soil depth increments collected during 2005 and 2006 from three annual no-till crop sequences in a long-term experiment near Heppner, OR

\begin{tabular}{|c|c|c|c|c|c|c|c|c|c|}
\hline \multirow{2}{*}{$\begin{array}{l}\text { Soil depth } \\
\text { (cm) }\end{array}$} & \multicolumn{3}{|c|}{ Annual HRSWa (COS112) } & \multicolumn{3}{|c|}{ Annual SWSW (COS113) } & \multicolumn{3}{|c|}{ Annual SB (COS114) } \\
\hline & Mean $^{b}$ & Incr. $\% \mathrm{c}$ & Cum. \%d & Mean & Incr. \% & Cum. \% & Mean & Incr. \% & Cum. \% \\
\hline $0-15$ & 4,657 & 48 & 48 & 1,851 & 20 & 20 & 400 & 14 & 14 \\
\hline $15-30$ & 3,898 & 41 & 89 & 1,819 & 19 & 39 & 811 & 28 & 42 \\
\hline $30-45$ & 916 & 10 & 98 & 2,801 & 30 & 69 & 937 & 33 & 75 \\
\hline $45-60$ & 97 & 1 & 99 & 2,738 & 29 & 99 & 690 & 24 & 99 \\
\hline $60-90$ & 9 & 0 & 100 & 130 & 1 & 100 & 38 & 1 & 100 \\
\hline $90-120$ & 42 & 0 & 100 & 1 & 0 & 100 & 5 & 0 & 100 \\
\hline$P>F$ & $<0.001$ & & & $<0.001$ & & & 0.003 & & \\
\hline $\mathrm{LSD}_{0.05}$ & 29 & & & 6 & & & 35 & & \\
\hline $\mathrm{CV}(\%)$ & 44 & & & 28 & & & 37 & & \\
\hline$n^{e}$ & 52 & & & 55 & & & 51 & & \\
\hline
\end{tabular}

${ }^{\mathrm{a}} \mathrm{HRSW}=$ hard red spring wheat, SWSW = soft white spring wheat, and SB = spring barley.

${ }^{\mathrm{b}}$ Means and LSD are back-transformed; means are based on five replicates per depth increment for each of the 2 years.

${ }^{c}$ Percentage of the total population found in the indicated soil depth interval.

${ }^{\mathrm{d}}$ Cumulative percentage of the total population from soil surface to the indicated soil depth interval.

${ }^{\mathrm{e}}$ Data points used in the analysis. 
$31 \%$ ). Sampling to 30 or $45 \mathrm{~cm}$ depth revealed little distinction between populations in annual crops and wheat-fallow rotations.

Likewise, the estimate that $25 \%$ of Oregon and Washington fields are infested with potentially damaging populations of Pratylenchus spp. (18) must now be considered highly conservative. We now estimate that economically important populations of Pratylenchus spp. (>2,000 per kg of soil) may occur in as many as $60 \%$ of PNW dryland fields. However, it is also recognized that Pratylenchus spp. occur at very low population densities throughout the soil profiles of wheat-fallow rotations in some low-rainfall environments such as Lind, Ralston, and Ritzville, WA (unpublished data). Although populations were very low to nondetectable in wheat-fallow rotations at those three locations, much higher populations occurred throughout the soil profiles of annual cropping sequences at the same locations, and particularly where an annual crop was also irrigated.

Thompson et al. (27) reported that Pratylenchus spp. populations reduced by tolerant and resistant crops increased to damaging levels following as few as two wheat crops. We observed a similar response in two fields near Heppner, ONF1 and DBRF1. Four successive barley crops were grown in DBF1 from 1999 to 2002 . It is likely that in 2002 the DBRF1 field would have had a low $P$. neglectus population similar to those in the ONF1 and COS114 fields in 2005, which also had successive years of cropping with barley. Winter wheat, spring wheat, and mustard were grown on DBF1 during 2003, 2004, and 2005, respectively, and after these three susceptible crops, the $P$. neglectus population was very high throughout the $90-\mathrm{cm}$ soil profile, and was particularly high in the surface $15 \mathrm{~cm}$ depth interval. Smiley et al. (21) measured wheat yield losses up to $40 \%$ in fields with similar $P$. neglectus populations in the surface $15 \mathrm{~cm}$. Spring barley grown in DBRF1 during 2006 reduced the $P$. neglectus population to less than 1,000 per $\mathrm{kg}$ throughout the $90-\mathrm{cm}$ soil profile. A single wheat crop grown in DBF1 in 2007 increased the $P$. neglectus population in the upper $45 \mathrm{~cm}$ of soil to a level nearly as high as found following the earlier sequence of two wheat and one mustard crop. Although spring barley clearly reduced Pratylenchus spp. populations in annual cropping systems in Oregon and also produced greater yield than spring wheat $(35 \%)$ and winter wheat (6 to 29\%) at Heppner (9), production of wheat is favored because it is generally more profitable than barley and also poses less year-to-year economic risk $(8,15)$.

The no-till (chemical fallow) COS111 treatment near Heppner had higher $P$. neglectus populations in 2006 than the conventionally tilled COS 115 and COS116 treatments in 2005 and 2006. Strausbaugh et al. (22) also detected higher populations of Pratylenchus spp. in reduced than in conventionally tilled dryland cropping systems. In contrast, Brmež et al. (2) reported that tillage did not significantly reduce Pratylenchus spp. populations, and Smiley et al. (18) found Pratylenchus populations to be similar in no-tilled and conventionally tilled soils in wheat-fallow rotations. In view of the high populations found in both cultivated and chemical fallows in this study, it is unlikely that population differences due to tillage, if any, are of biological significance in determining levels of potential yield reduction from Pratylenchus spp.

Deep samplings of soil profiles should be conducted to develop initial familiarity with the vertical distribution of Pratylenchus spp. in the silt loam profiles of PNW dryland farming systems. An appropriate sampling depth can then be established to collect an adequate proportion of the population for use in crop management decisions. At the locations sampled in this study, sampling to a depth of $30 \mathrm{~cm}$ always detected more than $50 \%$ of the total population and was considered adequate for most crop management decisions. A higher level of detection ( $>75 \%$ ) and understanding of population dynamics was achieved in most $(>75 \%)$ fields sampled to a depth of $45 \mathrm{~cm}$.

\section{ACKNOWLEDGMENTS}

We gratefully acknowledge growers William Jepsen and Eugene Logan, and scientist Stephen Machado (Oregon State University), for allowing samples to be collected from their farms and research trials. We also thank Tina Zeckman, Jonathon Jackson, Alison Thompson, and Deborah Hyatt for technical assistance, and Karl Rhinhart, Erling Jacobsen, and Paul Thorgersen for assistance with equipment and facilities. This research was funded by an OSU subcontract to the USDAAgricultural Research Service; SCA\#58-5348-4464, "Control of Root Diseases of Wheat and Barley".

\section{LITERATURE CITED}

1. Bell, N. L., and Watson, R. N. 2001. Optimising the Whitehead and Hemming tray method to extract plant parasitic and other nematodes from two soils under pasture. Nematology 3:179-185.

2. Brmež, M., Ivezić, M., and Raspudić, E. 2006. Effect of mechanical disturbances on nematode communities in arable land. Helminthologia 43:117-121.

3. Castillo, P., and Vovlas, N. 2007. Pratylenchus, Nematoda, Pratylenchidae: Diagnosis, biology, pathogenicity and management. Nematol. Monogr. Perspectives 6:1-530.

4. Doyle, A. D., McLeod, R. W., Wong, P. T. W., Hetherington, S. E., and Southwell, R. J. 1987. Evidence for the involvement of the root lesion nematode Pratylenchus thornei in wheat yield decline in northern New South Wales. Aust. J. Exp. Agric. 27:563-570.

5. Hafez, S. L., Golden, A. M., Rashid, F., and Handoo, Z. 1992. Plant-parasitic nematodes associated with crops in Idaho and Eastern Oregon. Nematropica 22:193-204.

6. Handoo, Z. A., and Golden, A. M. 1989. A key and diagnostic compendium to the species of the genus Pratylenchus Filipjev, 1936 (Lesion Nematodes). J. Nematol. 21(2):202-218.
7. Hollaway, G. J., Taylor, S. P., Eastwood, R. F. and Hunt, C. H. 2000. Effect of field crops on population densities of Pratylenchus in southeastern Australia; Part 2: P. thornei. J. Nematol. 32:600-608.

8. Juergens, L. A., Young, D. L., Schillinger, W. F., and Hinman, H. R. 2004. Economics of alternative no-till spring crop rotations in Washington's wheat-fallow region. Agron. J. 96:154-158.

9. Machado, S., Petrie, S., Rhinhart, K., and Qu, A. 2007. Long-term continuous cropping in the Pacific Northwest: Tillage and fertilizer effects on winter wheat, spring wheat, and spring barley production. Soil Till. Res. 94:473-481.

10. Machado, S., Pritchett, L., Jacobsen, E., Petrie, S., Smiley, R., Ball, D., Wysocki, D., Wuest, S., Gollany, H., and Jepsen, W. 2006. Longterm experiments at CBARC-Moro and Center of Sustainability, Heppner 2005. Oregon Agric. Exp. Stn. Spec. Rep. 1068:40-49.

11. McSorley, R. 1987. Extraction of nematodes and sampling methods. Pages 13-47 in: Principles and Practice of Nematode Control in Crops. R. H. Brown and B. R. Kerry, eds. Academic Press, Sydney, Australia.

12. McSorley, R., and Dickson, D. W. 1990. Vertical distribution of plant-parasitic nematodes in sandy soil under maize. Plant Soil 123:95-100.

13. Proctor, J. R., and Marks, C. F. 1974. The determination of normalising transformations for nematode count data from soil samples and of efficient sampling schemes. Nematologica 20:395-406.

14. Pudasaini, M. P., Schomaker, C. H., Been, T. H., and Moens, M. 2006. Vertical distribution of the plant-parasitic nematode, Pratylenchus penetrans, under four field crops. Phytopathology 96:226-233.

15. Schillinger, W. F., Kennedy, A. C., and Young, D. L. 2007. Eight years of annual no-till cropping in Washington's winter wheat-summer fallow region. Agric. Ecosyst. Environ. 120:345-358.

16. Sheedy, J. G., Smiley, R. W., Easley, S. A., and Thompson, A. L. 2007. Resistance reaction of Pacific Northwest spring wheat and barley cultivars to root-lesion nematode, 2007. Plant Disease Management Reports (online). Report 1:CF022. DOI: 10.1094/PDMR01. American Phytopathological Society, St. Paul, MN.

17. Shurtleff, M. C., and Averre, C. W., III. 2000. Diagnosing Plant Diseases caused by Nematodes. American Phytopathological Society, St Paul, MN.

18. Smiley, R. W., Merrifield, K., Patterson, L.-M., Whittaker, R. G., Gourlie, J. A., and Easley, S. A. 2004. Nematodes in dryland field crops in the semiarid Pacific Northwest United States. J. Nematol. 36:54-68.

19. Smiley, R. W., and Nicol, J. M. 2009. Nematodes which challenge global wheat production. In: Wheat: Science and Trade. B. F. Carver, ed. Blackwell Publishing, Ames, IA. In press.

20. Smiley, R. W., Whittaker, R. G., Gourlie, J. A., and Easley, S. A. 2005. Pratylenchus thorne associated with reduced wheat yield in Oregon. J. Nematol. 37:45-54.

21. Smiley, R. W., Whittaker, R. G., Gourlie, J. A., and Easley, S. A. 2005. Suppression of wheat growth and yield by Pratylenchus neglectus in the Pacific Northwest. Plant Dis. 89:958-968.

22. Strausbaugh, C. A., Bradley, C. A., Koehn, A. C., and Forster, R. L. 2004. Survey of root diseases of wheat and barley in southeastern Idaho. Can. J. Plant Pathol. 26:167-176.

23. Taylor, S. P., and Evans, M. L. 1998. Vertical and horizontal distribution of and soil sampling for root lesion nematodes (Pratylenchus neglectus and $P$. thornei) in South Australia. Australas. Plant Pathol. 27:90-96.

24. Taylor, S. P., Hollaway, G. J., and Hunt, C. H. 2000. Effect of field crops on population den- 
sities of Pratylenchus neglectus and P. thornei in southeastern Australia; Part 1: P. neglectus. J. Nematol. 32:591-599.

25. Thompson, J. P., Brennan, P. S., Clewett, T. G., Sheedy, J. G., and Seymour, N. P. 1999. Progress in breeding wheat for tolerance and resistance to root-lesion nematode (Pratylenchus thornei). Australas. Plant Pathol. 28:45-52.

26. Thompson, J. P., Mackenzie, J., and Amos, R. 1995. Root-lesion nematode (Pratylenchus thornei) limits response of wheat but not barley to stored soil moisture in the Hermitage long-term tillage experiment. Aust. J. Exp. Agric. 35:1049-1055.

27. Thompson, J. P., Owen, K. J., Stirling, G. R., and Bell, M. J. 2008. Root lesion nematodes (Pratylenchus thornei and P. neglectus): Progress in managing a significant pest of grain crops in northern Australia. Australas. Plant Pathol. 37:235-242.
28. Vanstone, V. A., Hollaway, G. J., and Stirling, G. R. 2008. Managing nematode pests in the southern and western regions of the Australian cereal industry: Continuing progress in a challenging environment. Australas. Plant Pathol. 37:220-234.

29. Whitehead, A. G., and Hemming, J. R. 1965. A comparison of some quantitative methods of extracting small vermiform nematodes from soil. Ann. Appl. Biol. 55:25-38. 